\title{
Oral vitamin D supplementation at five times the recommended allowance marginally affects serum 25-hydroxyvitamin D concentrations in dogs
}

\author{
Lauren R. Young* and Robert C. Backus \\ Department of Veterinary Medicine and Surgery, College of Veterinary Medicine, University of Missouri, Columbia, MO 65211, USA
}

(Received 14 January 2016 - Final revision received 28 April 2016 - Accepted 2 June 2016)

Journal of Nutritional Science (2016), vol. 5, e31, page 1 of 9

doi:10.1017/jns.2016.23

Abstract

Little is known regarding optimal vitamin D status in adult dogs. To date no studies on vitamin D supplementation for improving vitamin D status have been reported for adult dogs. The aims of this study were to identify dogs with low vitamin $\mathrm{D}$ status and evaluate an oral dosage of cholecalciferol $\left(\mathrm{D}_{3}\right)$ for effectiveness in increasing vitamin D status. For this, forty-six privately owned dogs were evaluated. Of the dogs, thirty-three (or $71.7 \%$ ) had serum 25 hydroxyvitamin D (25(OH)D) concentrations less than $100 \mathrm{ng} / \mathrm{ml}$, a minimum previously suggested for vitamin D sufficiency in dogs. Subsequently, thirteen dogs were enrolled in a supplementation trial. Dogs were given either a $\mathrm{D}_{3}$ supplement $\left(n 7 ; 2 \cdot 3 \mu \mathrm{g} / \mathrm{kg}^{0.75}\right)$ or olive oil placebo (n 6) daily with food. Serum concentrations of $25(\mathrm{OH}) \mathrm{D}$ were determined at weeks 1,3 and 6 , and at the trial end. Only at the trial end (weeks 9-10) was 25(OH)D significantly greater $(P=0.05)$ in supplemented $v$. placebo dogs. Serum concentrations of $24 \mathrm{R}, 25$-dihydroxycholecalciferol determined at the trial end were about $40 \%$ of that of $25(\mathrm{OH}) \mathrm{D}_{3}$ and not significantly different between the groups. Concentrations of parathyroid hormone, ionised Ca, $\mathrm{P}$ and creatinine measured in initial and final serum samples indicated supplementation caused no toxicity. We conclude that vitamin $\mathrm{D}_{3}$ supplementation at a dosage near the National Research Council recommended safe-upper limit was not effective for rapidly raising serum $25(\mathrm{OH}) \mathrm{D}$ concentrations in healthy, adult dogs. Further work is needed in evaluating the metabolism of orally administered $\mathrm{D}_{3}$ in dogs before dosing recommendations can be made.

Key words: Cholecalciferol: 25-Hydroxyergocalciferol: 24R, 25-dihydroxycholecalciferol: Parathyroid hormone: Ionised calcium

Vitamin D has been extensively studied in human medicine since the discovery of its essentiality in the development and maintenance of a normal skeleton in the early 1900s. It is now known that through the interaction of vitamin $\mathrm{D}$ receptors in over forty tissues in the body, effects of 1,25-dihydroxyvitamin $\mathrm{D}_{3}(1,25$ $\left.(\mathrm{OH})_{2} \mathrm{D}_{3}\right)$ go beyond $\mathrm{Ca}$ homeostasis and the prevention of rickets and osteomalacia to involve almost all body systems ${ }^{(1)}$.

It is widely accepted that the best indicator of vitamin $\mathrm{D}$ status is serum 25-hydroxyvitamin D $(25(\mathrm{OH}) \mathrm{D})$, as it is the most abundant circulating metabolite of vitamin $\mathrm{D}$, and its concentration is determined by vitamin $\mathrm{D}$ intake ${ }^{(2)}$. Numerous reports have defined sufficient vitamin D status in people by evaluating the well-established inverse relationship between serum concentrations of $25(\mathrm{OH}) \mathrm{D}$ and parathyroid hormone $(\mathrm{PTH})^{(3-6)}$. The $25(\mathrm{OH}) \mathrm{D}$ concentration at the inflection point of PTH, beyond which little further decrease in PTH is observed, has been interpreted as indicative of optimal Ca homeostasis and a marker of vitamin D sufficiency in people. However, this has led to some controversy in the definition of sufficient vitamin $\mathrm{D}$ status in people, as estimates of $25(\mathrm{OH}) \mathrm{D}$ concentrations necessary to suppress PTH concentrations have been variable ${ }^{(7)}$.

Recently the Institute of Medicine has recommended vitamin $\mathrm{D}$ deficiency in people be defined as $25(\mathrm{OH}) \mathrm{D}$

Abbreviations: $1,25(\mathrm{OH})_{2} \mathrm{D}_{3}, 1,25$-dihydroxyvitamin $\mathrm{D}_{3} ; 24 \mathrm{R}, 25(\mathrm{OH})_{2} \mathrm{D}_{3}, 24 \mathrm{R}, 25$-dihydroxyvitamin $\mathrm{D}_{3} ; 25(\mathrm{OH}) \mathrm{D}, 25$-hydroxyvitamin $\mathrm{D} ; 25(\mathrm{OH}) \mathrm{D}_{2}$, 25-hydroxyergocalciferol; $25(\mathrm{OH}) \mathrm{D}_{3}, 25$-hydroxycholecalciferol; BW, body weight; CLIA, chemiluminesence immunoassay; iCa, ionised Ca; NRC, National Research Council; PTH, parathyroid hormone.

*Corresponding author: L. R. Young, fax +1 573884 7563, email younglaur@missouri.edu 
concentrations less than $20 \mathrm{ng} / \mathrm{ml}$ and insufficiency defined as $21-29 \mathrm{ng} / \mathrm{ml}^{(8)}$. While concentrations that are defined as insufficient are adequate for the prevention of bone disease, a growing body of evidence exists that concentrations greater than $30 \mathrm{ng} / \mathrm{ml}$ and closer to $40 \mathrm{ng} / \mathrm{ml}$ are desirable for optimal health and the prevention of chronic disease in people ${ }^{(9)}$. However, estimates are that $20-100 \%$ of US, Canadian and European elderly men and women are vitamin D deficient, and current recommended allowances for vitamin D are unlikely to achieve sufficient vitamin $\mathrm{D}$ status for most people ${ }^{(8,9)}$.

Despite the vast research on vitamin D and health in people, no studies had attempted to define vitamin $\mathrm{D}$ sufficiency in adult dogs until recently. Comparing the relationship between $25(\mathrm{OH}) \mathrm{D}$ concentrations and intact PTH (iPTH), similar to human studies, investigators found that the median and variance in iPTH observations among dogs declined to a plateau when $25(\mathrm{OH}) \mathrm{D}$ concentrations were at $100 \mathrm{ng} / \mathrm{ml}^{(10)}$. A similarly significant drop in variability of mean serum canine C-reactive protein concentrations, a marker of chronic inflammation, was observed to occur at $25(\mathrm{OH}) \mathrm{D}$ concentrations of $100-120 \mathrm{ng} / \mathrm{ml}$. Additionally, this study showed a decrease in the relative risk of developing cancers as $25(\mathrm{OH}) \mathrm{D}$ concentrations increased. While we believe these findings should be reproduced, this information provides novel evidence on which to base evaluation of vitamin $\mathrm{D}$ sufficiency in adult dogs for the prevention of chronic disease. However, reports of serum $25(\mathrm{OH}) \mathrm{D}$ concentrations amongst apparently healthy dogs widely differ ${ }^{(10-13)}$, with many that would be considered to have insufficient vitamin D status, based on this definition.

Unlike humans and several other species, dogs are unable to endogenously synthesise vitamin $\mathrm{D}_{3}$ in their skin in response to UV light ${ }^{(14)}$. Therefore, dogs are reliant upon their diet to supply their vitamin $\mathrm{D}$ requirements, primarily from the intake of vitamin $\mathrm{D}_{3}$ (cholecalciferol), but also vitamin $\mathrm{D}_{2}$ (ergocalciferol). The dietary vitamin $\mathrm{D}$ requirement for adult dogs has not been clearly established. The current recommended allowance by the National Research Council (NRC) is based on findings of studies identifying dietary concentrations of vitamin $\mathrm{D}$ that prevent skeletal abnormalities in puppies. In the absence of long-term studies in adult and pregnant and lactating dogs, dietary recommendations made for puppies are extrapolated to all life stages ${ }^{(15)}$, which may not be reflective of intake needed to achieve a specific health outcome.

In veterinary medicine, many investigators have reported associations between low serum 25(OH)D concentrations and canine mast cell tumour ${ }^{(16)}$, chronic kidney disease ${ }^{(17)}$, congestive heart failure ${ }^{(18)}$, inflammatory bowel disease ${ }^{(19)}$ and cancer ${ }^{(10)}$. Although cause and effect has not been established, these studies provide a basis for which vitamin D supplementation has the potential to improve health status, decrease disease risk, and be used as adjunct therapy in many diseases of dogs. To date, no published studies have reported on the effectiveness of oral vitamin $\mathrm{D}$ supplementation for increasing serum $25(\mathrm{OH}) \mathrm{D}$ concentration in dogs. Therefore, the aims of our study were to identify dogs with low vitamin D status as previously defined ${ }^{(10)}$ and evaluate responsiveness to vitamin $\mathrm{D}_{3}$ supplementation. Our hypothesis was that vitamin $\mathrm{D}_{3}$ supplementation at a daily dosage that is five times the NRC recommended allowance, but within the margins of the NRC safe upper limit, would effectively and efficiently raise vitamin $\mathrm{D}$ status without causing biochemical disturbances consistent with vitamin $\mathrm{D}$ toxicity when given to dogs with low $25(\mathrm{OH}) \mathrm{D}$ concentrations.

\section{Materials and methods}

\section{Animals: vitamin D status survey}

Following solicitation on our university campus announcement list-serve, forty-six privately owned, adult dogs aged $1 \cdot 25-12 \cdot 0$ years (median $5 \cdot 0$ years) were volunteered for evaluation of vitamin D status. Various breeds were represented with sex distribution being thirteen male neutered (MN), thirty-two female spayed (FS) and one female intact. Body weights (BW) ranged from 5.3 to $49.0 \mathrm{~kg}$ (median $22.5 \mathrm{~kg}$ ) with body condition scores of 4-8/9 (median 5/9). All dogs were reported by their owners as clinically healthy at the time of evaluation. Excluded were dogs weighing less than $2 \cdot 2 \mathrm{~kg}$, clinically ill dogs, those currently on vitamin supplements or medications that may alter $\mathrm{Ca}, \mathrm{P}$ or vitamin $\mathrm{D}$ homeostasis or those on apparently nutritionally unbalanced diets. Owners completed a questionnaire regarding diet, environment, and current medications and medical conditions. Owners signed an informed consent form before participation which included the possibility of entry into a subsequent vitamin D supplementation trial if their dog was found to have low vitamin $\mathrm{D}$ status. The consent form and animal use protocol were reviewed and approved by our institution's animal care and use committee.

\section{Study design}

BW and body and muscle condition scores were recorded for each dog at the time of blood collection. Approximately $5 \mathrm{ml}$ of blood were collected from either the jugular or cephalic vein following an overnight food withholding. Extracted serum was stored at $-20^{\circ} \mathrm{C}$ for later analysis of $25(\mathrm{OH}) \mathrm{D}$ concentration.

\section{Animals: vitamin D supplementation trial}

Owners of thirteen dogs (four MN, nine FS) that were found to have low vitamin $\mathrm{D}$ status in the survey accepted participation in a clinical trial to evaluate the efficacy of oral vitamin $\mathrm{D}_{3}$ supplementation to improve vitamin D status. Signalment and other information for the groups are given in Table 1. Most of the dogs were housed primarily indoor with one dog both indoor and outdoor and one outdoor only. Complete diet histories were available for twelve of the thirteen dogs, of which eleven different commercially available dry diets were fed. The diets were labelled to indicate having undergone animal feed testing ( $n$ 8) or formulation $(n 3)$ to meet Association of American Feed Control Officials (AAFCO) dog food nutrient profiles for adult maintenance $(n 9)$ or all life stages $(n 2)$. The vitamin $\mathrm{D}$ content of these diets was obtained by 
Table 1. Signalment and body condition data for dogs in the control $(n 6)$ and treatment $(n 7)$ groups of the vitamin D supplementation trial (Medians and ranges)

\begin{tabular}{|c|c|c|c|c|}
\hline & \multicolumn{4}{|c|}{ Group } \\
\hline & \multicolumn{2}{|c|}{ Control } & \multicolumn{2}{|c|}{ Treatment } \\
\hline & Median & Range & Median & Range \\
\hline Body weight (kg) & 31 & $13-49$ & 28 & $13-39$ \\
\hline $\begin{array}{l}\text { Body condition score } \\
\quad(1-9 / 9)\end{array}$ & 5 & $5-7$ & 5 & $4-6$ \\
\hline Age (years) & 6.5 & $3 \cdot 5-12 \cdot 0$ & 5.0 & $3.0-11.0$ \\
\hline Breeds & \multicolumn{2}{|c|}{$\begin{array}{l}\text { Rottweiler (1), } \\
\text { golden retriever } \\
\text { (2), beagle (1), } \\
\text { Australian } \\
\text { shepherd (1), } \\
\text { mixed breed (1) }\end{array}$} & \multicolumn{2}{|c|}{$\begin{array}{l}\text { Labrador retriever } \\
(2), \text { golden } \\
\text { retriever (1), } \\
\text { bloodhound (1), } \\
\text { Boston terrier (1), } \\
\text { Weimaraner (1), } \\
\text { mixed breed (1) }\end{array}$} \\
\hline
\end{tabular}

Table 2. Vitamin D content of diets fed and estimation of vitamin D intake from diet and supplement for dogs with complete owner-provided diet histories

(Medians and ranges)

\begin{tabular}{|c|c|c|c|c|}
\hline & \multicolumn{4}{|c|}{ Group } \\
\hline & \multicolumn{2}{|c|}{ Control } & \multicolumn{2}{|c|}{ Treatment† } \\
\hline & Median & Range & Median & Range \\
\hline Dogs $(n)$ & 5 & & 7 & \\
\hline Intake (kJ/d) & 4420 & $2630-6700$ & 4140 & $1540-7350$ \\
\hline $\begin{array}{l}\text { Vitamin } D(\mu \mathrm{g} / 418.4 \mathrm{~kJ} / \\
\text { diet) }\end{array}$ & 1.9 & $0.6-2.6$ & 0.5 & $0 \cdot 3-2 \cdot 0$ \\
\hline $\begin{array}{l}\text { Vitamin D intake from } \\
\text { diet }\left(\mu \mathrm{g} / \mathrm{kg} \mathrm{BW}^{0.75}\right)\end{array}$ & 1.9 & $0.6-2 \cdot 3$ & 0.4 & $0.2-1.8^{*}$ \\
\hline $\begin{array}{l}\text { Vitamin D intake from } \\
\text { supplement }(\mu \mathrm{g} / \mathrm{kg} \\
\left.\mathrm{BW}^{0.75}\right)\end{array}$ & 0 & & $2 \cdot 3$ & $2 \cdot 2-2 \cdot 3 \ddagger$ \\
\hline
\end{tabular}

BW, body weight.

* Values were significantly different between control and treatment groups $(P=0.03$; Wilcoxon two-sample test).

† Daily oral vitamin $D_{3}$ supplementation, $2.3 \mu \mathrm{g} / \mathrm{kg}^{0.75}$

$\ddagger$ Value based on measurement of vitamin $D$ in supplement at the beginning of the trial.

contacting the manufacturing company for a typical analysis of the final product, which all companies provided on an energy and as-is basis. Total daily vitamin $\mathrm{D}$ intake was calculated for twelve dogs by considering the amount of vitamin $\mathrm{D}$ present in the diet as provided by the manufacturers, food intake history from owners, and the dog's metabolic BW. The remaining dog was fed ad libitum, and the specific formulation of diet varied at times according to the owner, therefore obtaining dietary vitamin $\mathrm{D}$ content from the manufacturer or estimating dietary vitamin $\mathrm{D}$ intake was not possible. One diet fed to two dogs belonging to the same household did not meet AAFCO minimum vitamin $\mathrm{D}$ requirements on an energy basis. Based on food intake information provided by the owner, these dogs were not consuming enough diet to meet the NRC adequate intake of vitamin $\mathrm{D}$ on a metabolic BW basis $(0.36 \mu \mathrm{g} /$ $\mathrm{kg}^{0.75}$ ) (Table 2).

\section{Study design}

Immediately prior to entry into the trial, jugular or cephalic blood was again obtained following an overnight food withholding. A complete blood count with manual differential and clinical serum chemistry panel was obtained to screen each $\operatorname{dog}$ for underlying disease and to determine baseline values. Serum was stored at either -20 or $-80^{\circ} \mathrm{C}$ in plastic tubes for later determinations of PTH and ionised Ca (iCa). The $\operatorname{dogs}$ were assigned to a control $(n 6)$ or treatment group $(n 7)$ based on the need for balancing for size of the groups, as well as age, sex and BW. Dogs belonging to the same household were assigned to the same group. Owners were blinded as to which group their dog was assigned.

Dogs of the treatment group received a vitamin $\mathrm{D}_{3}$ supplement in olive oil. The supplement was made by dissolving 29 $\mathrm{mg}$ vitamin $\mathrm{D}_{3}$ (cholecalciferol; Sigma-Aldrich) in $1.26 \mathrm{ml}$ of ethanol and mixing $1 \mathrm{ml}$ of the solution into $900 \mathrm{~g}$ of purified olive oil (Great Value; Wal-Mart Stores) to yield a concentration of $23 \mathrm{mg} / \mathrm{l}$ or $23 \mu \mathrm{g}$ of vitamin $\mathrm{D}_{3} / \mathrm{ml}$. The contents of one capsule of vitamin E (vitamin E supplement $1000 \mathrm{IU}$, Spring Valley; Wal-Mart Stores) were added to prevent oxidation of polyunsaturated fat (PUFA) in the oil during storage ( $1 \mathrm{mg}$ DL- $\alpha$-tocopherol/ $1 \mathrm{~g}$ of PUFA). The control group received a placebo of the same olive oil, prepared in the same manner with vitamin E. Once prepared, the supplement and control oil stock was stored in a dark cabinet at room temperature. Treatment and control dogs were dosed based on metabolic BW $\left(0.1 \mathrm{ml} / \mathrm{kg} \mathrm{BW}{ }^{0.75}\right.$ per d). At this dosage, treatment dogs received approximately $2 \cdot 3 \mu \mathrm{g}$ vitamin $\mathrm{D}_{3} / \mathrm{kg} \mathrm{BW} \mathrm{BW}^{0.75}$ per $\mathrm{d}$, an amount that is 5.1 times the recommended allowance but does not exceed the safe upper limit recommended by the NRC for maintenance of adult dogs $\left(2.6 \mu \mathrm{g} / \mathrm{kg} \mathrm{BW}^{0.75}\right)^{(20)}$. Owners applied the daily dose to food and were instructed not to alter diet, environment and exercise schedule during the trial.

Dogs were re-evaluated after initiating treatment or placebo supplement at weeks 1, 3, 6, and at the trial end, weeks 9-10. At each evaluation, venous blood was collected following an overnight food withholding, and serum was harvested for total $25(\mathrm{OH}) \mathrm{D}$ analysis. At the end of the trial, additional serum was obtained for analysis of: 24R,25-dihydroxyvitamin $\mathrm{D}_{3}\left(24 \mathrm{R}, 25(\mathrm{OH})_{2} \mathrm{D}_{3}\right), 25$-hydroxycholecalciferol $\left(25(\mathrm{OH}) \mathrm{D}_{3}\right)$ and 25-hydroxyergocalciferol $\left(25(\mathrm{OH}) \mathrm{D}_{2}\right), \mathrm{PTH}, \mathrm{iCa}, \mathrm{P}$ and creatinine. Owner compliance was assessed by weighing the dog's supplement prior to dispensing and at the conclusion of the trial. Vitamin $\mathrm{D}_{3}$ concentration was analysed in retained treatment oil stock and treated supplement returned by owners.

\section{Laboratory analyses}

The complete blood counts (Sysmex xT-2000i; Sysmex America, Inc.) and clinical serum chemistry analyses (Beckman AU 400e; Beckman Coulter, Inc.) were performed at the University of Missouri Veterinary Medical Diagnostic Laboratory (Columbia, MO, USA). Serum total 25(OH)D was evaluated by a commercial laboratory (Veterinary 
Diagnostics Institute, Simi Valley, CA, USA) using a validated $25(\mathrm{OH}) \mathrm{D}$ assay (LIAISON; DiaSorin, Inc.). The assay is a direct, competitive chemiluminesence immunoassay (CLIA) for the quantitative determination of $25(\mathrm{OH}) \mathrm{D}$ in serum. The assay has been validated for use in dogs with an intra- and inter-assay coefficient of variation of 4.0 and $3.4 \%$, respectively ${ }^{(10)}$.

Concentrations were determined for the vitamin $\mathrm{D}$ metabolites, $24 \mathrm{R}, 25(\mathrm{OH})_{2} \mathrm{D}_{3}, 25(\mathrm{OH}) \mathrm{D}_{2}$ and $25(\mathrm{OH}) \mathrm{D}_{3}$, in $0.5 \mathrm{ml}$ aliquots of thawed serum using a modification of a HPLC method previously reported ${ }^{(21)}$. For this, serum samples $(0.5 \mathrm{ml})$ were incubated overnight at about $4^{\circ} \mathrm{C}$ with internal standard (2000 disintegrations per min of $25-\left[26,27-{ }^{3} \mathrm{H}\right]$ hydroxyvitamin $\mathrm{D}_{3}$ ) prior to their extraction. AUC of HPLC peaks of $25(\mathrm{OH}) \mathrm{D}_{3}$ and $25(\mathrm{OH}) \mathrm{D}_{2}$ (Cerilliant) increased linearly with increasing mass of injected standard over the range of concentrations found in serum samples. Mobile phase was collected during $2 \mathrm{~min}$ periods coinciding with elution times of standards, $25(\mathrm{OH}) \mathrm{D}_{3}$ and $24 \mathrm{R}, 25(\mathrm{OH})_{2} \mathrm{D}_{3}$ (Santa Cruz Biotechnology). The $25(\mathrm{OH}) \mathrm{D}_{3}$ fraction was dried by centrifugal evaporation, reconstituted in $6 \mathrm{ml}$ of scintillation cocktail, and counted for ${ }^{3} \mathrm{H}$ decay (2000 CA Tri-Carb; Packard Instrument). The $24 \mathrm{R}, 25(\mathrm{OH})_{2} \mathrm{D}_{3}$ HPLC fraction was spiked with internal standard ( $10 \mathrm{ng}$ of $\left.25(\mathrm{OH}) \mathrm{D}_{3}\right)$, dried by centrifugal evaporation and reconstituted in $130 \mu \mathrm{l}$ of 20:80 ethanolhexanes, the mobile phase of a second HPLC method for quantifying $24 \mathrm{R}, 25(\mathrm{OH})_{2} \mathrm{D}_{3}$.

For the second HPLC method, $100 \mu \mathrm{l}$ of the reconstitute was injected into mobile phase flowing at $1.0 \mathrm{ml} / \mathrm{min}$ on a column (Capcell Pak NH2, UG80, $5 \mu \mathrm{m}, 4.6 \times 250 \mathrm{~mm}$; Shiseido) at ambient temperature $\left(21-23^{\circ} \mathrm{C}\right)$. The AUC of UV peaks $(265 \mathrm{~nm})$ of $24 \mathrm{R}, 25(\mathrm{OH})_{2} \mathrm{D}_{3}$ and $25(\mathrm{OH}) \mathrm{D}_{3}$ standards increased linearly with increasing mass of injected standard over the range of concentrations found in serum samples.

Serum PTH was evaluated by a commercial laboratory (Veterinary Diagnostics Institute, Simi Valley, CA, USA) with a direct, two-site, sandwich-type CLIA. The assay sensitivity, specificity, intra- and inter-assay CV have been previously reported ${ }^{(10)}$. iCa analyses were performed at Michigan State University Diagnostic Center for Population and Animal Health, Lansing, MI, USA (Nova 8 Plus; Nova Biomedical).

\section{Analysis of vitamin $D_{3}$ in supplement}

The vitamin $\mathrm{D}_{3}$ content in olive oil supplement was determined by a modification of a previously described method ${ }^{(22)}$. For each determination, $1 \mathrm{ml}$ of oil was extracted with $9 \mathrm{ml}$ of methanol to which was added $25 \mu \mathrm{g}$ of internal standard (Ergocalciferol; Supelco) dissolved in methanol. A portion of the extract $(10 \mu \mathrm{l})$ was injected onto an HPLC column $\left(2.0 \times 250 \mathrm{~mm}^{2}\right.$, Ultrasphere ODS $5 \mu \mathrm{m}$ Beckman Instruments) equilibrated with mobile phase (82:13:5, acetonitrile-methanol-water, by vol.) flowing at $0.3 \mathrm{ml} / \mathrm{min}$. Concentrations of vitamin $\mathrm{D}_{3}$ and internal standard were determined from AUC absorbance recorded at $265 \mathrm{~nm}$. The $\mathrm{CV}$ of vitamin $\mathrm{D}_{3}$ concentrations determined in the vitamin $\mathrm{D}_{3}$-containing supplement at $25 \mu \mathrm{g} / \mathrm{ml}$ was $2.3 \%$. The analyses were all run in the same batch.

\section{5-Hydroyxvitamin $D_{3}$ storage stability trial}

To determine optimal storage conditions for 25-hydroxyvitamin $\mathrm{D}_{3}$, its stability was assessed over a period of 15 weeks of freezing and $14 \mathrm{~d}$ of refrigeration. Pooled beagle serum ( $25 \mathrm{ml}$; Innovative Research) was used for these analyses, to which $25(\mathrm{OH}) \mathrm{D}_{3}(2.5 \mu \mathrm{g}$ in $0.25 \mathrm{ml}$ of methanol $)$ was added. Aliquots of $0.5 \mathrm{ml}$ of serum were stored in a refrigerator $\left(4^{\circ} \mathrm{C}\right)$ and in -20 and $-80^{\circ} \mathrm{C}$ freezers. On days 0 , $2,4,7,10$ and 14 , of refrigerator storage and weeks $1,2,3$, $5,7,9,12$ and 15 of freezer storage, $25(\mathrm{OH}) \mathrm{D}_{3}$ concentration was determined in duplicate aliquots by the method described for the analysis of serum $25(\mathrm{OH}) \mathrm{D}_{3}$. For this trial, $25(\mathrm{OH}) \mathrm{D}_{2}$ (50 ng in $10 \mu \mathrm{l}$ of methanol) was used as the internal standard in place of the ${ }^{3} \mathrm{H}$ label.

\section{Statistical analysis}

Statistical analyses were performed using proprietary software (Excel 2013, Microsoft; SAS® 9.3, SAS Institute, Inc.). Variable observations were considered normally distributed if calculated mean and median differed by less than $10 \%$, kurtosis and skew statistics were between 1 and -1 , and stem-leaf plots of observations indicated few outliers. All variable observations were found to be normally distributed except PTH, $\mathrm{iCa}$, vitamin $\mathrm{D}$ intake, and change in pre- to post-serum 25 $(\mathrm{OH}) \mathrm{D}$ concentration. Following log transformation, PTH observations were normally distributed. For normally distributed observations, the significance of differences in variable observations within and between control and treatment groups were determined with paired and two-sample $t$ tests, respectively. For non-normally distributed observations, central tendency and variation were expressed as median and range and variable differences within and between groups were tested for significance with signed-rank and Wilcoxon twosample tests, respectively. The significance of variable correlations was tested with Pearson correlation. $P$ values $\leq 0.05$ were considered significant.

Mean and standard deviation were calculated for the 25 $(\mathrm{OH}) \mathrm{D}$ concentrations observed among the thirteen participating dogs prior to entry into the supplementation trial. Using these values and group sizes of six and seven dogs for the control and treatment groups, respectively, it was estimated that at a power of $\beta=0 \cdot 8$, the mean difference in 25 $(\mathrm{OH}) \mathrm{D}$ concentrations between the groups would have to be greater than $25 \%$ to reach significance at $\alpha=0.05$.

\section{Results}

\section{Vitamin D survey}

Serum total $25(\mathrm{OH}) \mathrm{D}$ concentrations ranged from $34.7 \mathrm{ng} / \mathrm{ml}$ to above the linear range of the total $25(\mathrm{OH}) \mathrm{D}$ assay, $>150$ $\mathrm{ng} / \mathrm{ml}$. We did not request dilution and re-assay for the few serum samples ( $n$ 4) with concentrations $>150 \mathrm{ng} / \mathrm{ml}$ (Fig. 1). Thirty-three $\operatorname{dogs}(71.7 \%)$ had $25(\mathrm{OH}) \mathrm{D}$ values below the previously reported minimum concentration indicating sufficient vitamin $\mathrm{D}$ status of $100 \mathrm{ng} / \mathrm{ml}^{(10)}$. The mean 25 $(\mathrm{OH}) \mathrm{D}$ values for females and males were 82.7 (SD 26.0) and 


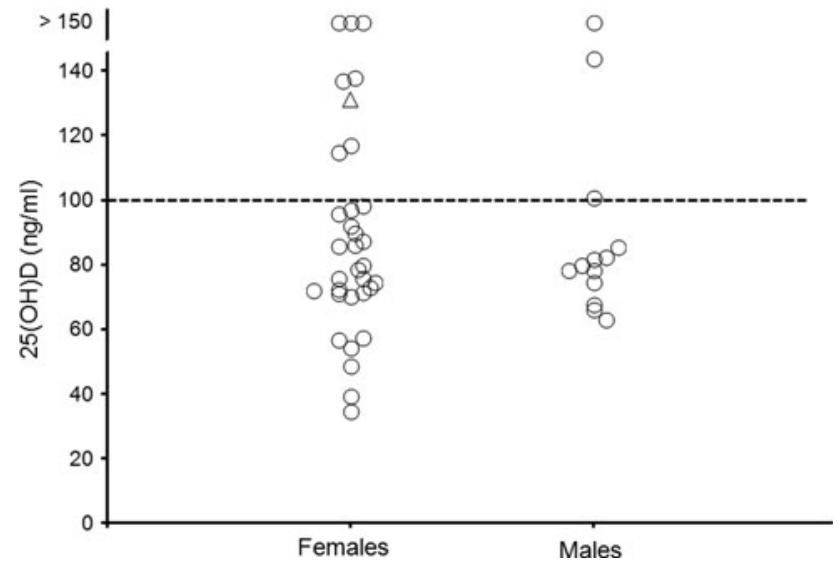

Fig. 1. Serum total 25-hydroxyvitamin $D(25(\mathrm{OH}) \mathrm{D})$ concentrations of female ( $n$ 33) and male $(n 13)$ adult dogs in vitamin $D$ status survey. $\Delta$, One intact female; ----, previously reported sufficient $25(\mathrm{OH}) \mathrm{D}$ status $(100 \mathrm{ng} / \mathrm{ml})$.

83.7 (SD 21.5) $\mathrm{ng} / \mathrm{ml}$, respectively, excluding the dogs with concentrations $>150 \mathrm{ng} / \mathrm{ml}$. The $25(\mathrm{OH}) \mathrm{D}$ concentrations were not significantly different between the two sexes.

\section{Vitamin D supplementation trial}

The mean total $25(\mathrm{OH}) \mathrm{D}$ concentrations for the control group were $66.2(\mathrm{SD} 8.8)$ and $71.3(\mathrm{SD} 8.4) \mathrm{ng} / \mathrm{ml}$ in the treatment group prior to entry into the trial. Significant differences were not found within either the control or treatment group for $25(\mathrm{OH}) \mathrm{D}$ concentrations prior to supplementation and at weeks 1, 3, 6 and 9-10. In addition, no significant difference was found between the control and treatment groups prior to vitamin $\mathrm{D}_{3}$ supplementation, and at 1,3 and 6 weeks later. Serum $25(\mathrm{OH}) \mathrm{D}$ concentrations were significantly greater $(P=0.05)$ in dogs in the treatment compared with the control group at weeks 9-10 (Fig. 2). However, analysis of the change in serum $25(\mathrm{OH}) \mathrm{D}$ concentrations from the beginning to end of the trial between the two groups did not reach significance. Initial and final serum $25(\mathrm{OH}) \mathrm{D}$ concentrations were not significantly correlated with initial and final serum $\mathrm{iCa}, \mathrm{PTH}$ or $\mathrm{P}$ concentrations for either the control or the treatment group. While estimated dietary vitamin $\mathrm{D}$ intakes of the control group were significantly greater $(P=0.03)$ than those of the treatment group, initial serum $25(\mathrm{OH}) \mathrm{D}$ concentrations were not significantly correlated with initial vitamin $\mathrm{D}$ intake estimates (Table 2).

\section{Laboratory analyses}

With only a few exceptions complete blood count and serum chemistry analyses results among the dogs were within the clinical laboratory reference ranges (Supplementary Table S1). Serum PTH, iCa, P and creatinine concentrations did not significantly change from the beginning to the end of the trial for either group. No significant difference was found for these variables between the control and treatment groups prior to and at the conclusion of the trial, except for iCa where the difference prior to entry into the trial was statistically significant between the groups (Table 3). Initial and

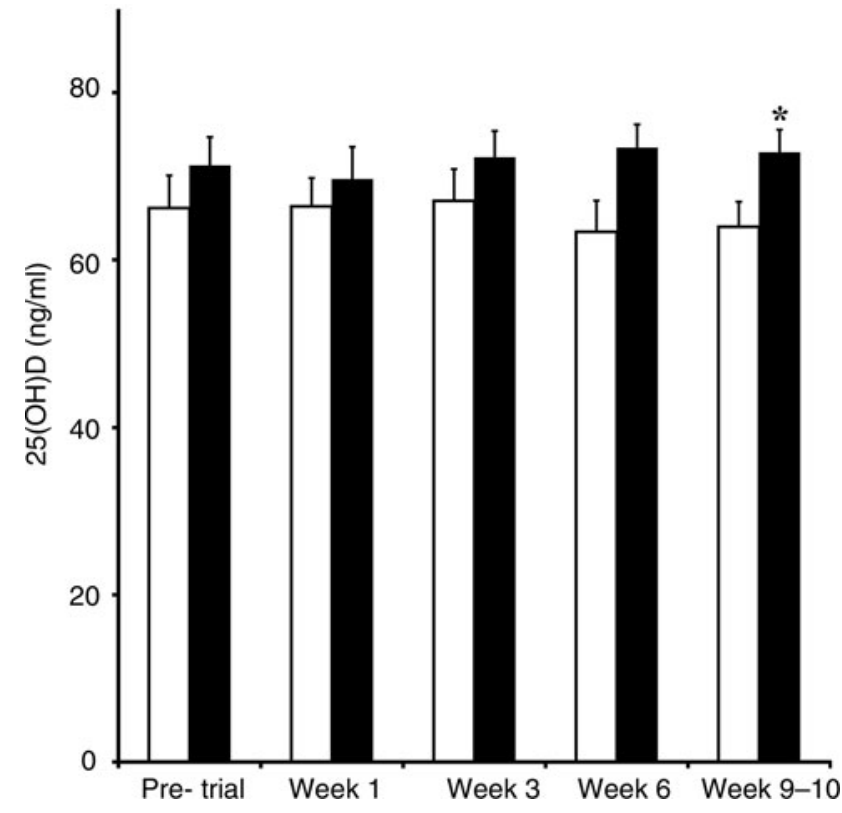

Fig. 2. Serum total concentrations of 25-hydroxyvitamin $D(25(\mathrm{OH}) \mathrm{D})$ for control $(\square ; n 6)$ and treatment $(\square ; n 7)$ groups prior to beginning the vitamin $D_{3}$ supplementation trial (pre-trial), and at weeks 1, 3, 6 and 9-10 after beginning supplementation. Values are means, with standard errors represented by vertical bars. * Mean value was significantly different from that of the control group $(P=0.05$; two-sample $t$ test).

final iCa concentrations were not significantly correlated with initial and final serum PTH concentrations for either the control or the treatment group.

\section{Vitamin D metabolites}

Extracts of serum samples used for quantification of vitamin D metabolites had clearly identifiable chromatographic peaks at retention times of standards for $25(\mathrm{OH}) \mathrm{D}_{3}$ and $24 \mathrm{R}, 25$ $(\mathrm{OH})_{2} \mathrm{D}_{3}$. A chromatographic peak coinciding with the retention time of $25(\mathrm{OH}) \mathrm{D}_{2}$ standard was not found in any extract. Calculated concentrations for serum $24 \mathrm{R}, 25(\mathrm{OH})_{2} \mathrm{D}_{3}$ were about $40 \%$ of those calculated for $25(\mathrm{OH}) \mathrm{D}_{3}$ (Table 4). They did not significantly correlate with the $25(\mathrm{OH}) \mathrm{D}_{3}$ concentrations. The mean $25(\mathrm{OH}) \mathrm{D}_{3}$ concentration of dogs of the treatment group was numerically greater than that of dogs of the control group, but this difference did not reach significance. Also, no significant difference was found between $24 \mathrm{R}, 25(\mathrm{OH})_{2} \mathrm{D}_{3}$ concentrations of the two groups.

\section{Analysis of vitamin $D_{3}$ in supplement}

The concentration of vitamin $\mathrm{D}_{3}$ in the stock supplement quantified at the conclusion of the trial was measured to be $20.7 \mu \mathrm{g} / \mathrm{ml}$, which was about $90 \%$ of the initially targeted inclusion. Each treatment supplement containing vitamin $\mathrm{D}_{3}$ dispensed to owners was quantified at the conclusion of the trial. The vitamin $\mathrm{D}_{3}$ concentrations ranged from 19.1 to $22.4 \mu \mathrm{g} / \mathrm{ml}$ (median $19.7 \mu \mathrm{g} / \mathrm{ml}$ ). The average measured concentration $(19.9 \mu \mathrm{g} / \mathrm{ml})$ represented a loss of $13 \%$ of initial targeted inclusion $(23 \mu \mathrm{g} / \mathrm{ml})$. 
Table 3. Serum biochemical analyses results for control $(n 6)$ and treatment $(n$ 7) groups prior to entry and at the conclusion of the vitamin $\mathrm{D}$ supplementation trial

(Medians and ranges)

\begin{tabular}{|c|c|c|c|c|c|c|c|c|}
\hline \multirow[b]{4}{*}{ Variable } & \multicolumn{8}{|c|}{ Group } \\
\hline & \multicolumn{4}{|c|}{ Control } & \multicolumn{4}{|c|}{ Treatment† } \\
\hline & \multicolumn{2}{|c|}{ Pre-trial } & \multicolumn{2}{|c|}{ End-trial } & \multicolumn{2}{|c|}{ Pre-trial } & \multicolumn{2}{|c|}{ End-trial } \\
\hline & Median & Range & Median & Range & Median & Range & Median & Range \\
\hline Intact PTH (pg/ml) & 16 & $6-27 \cdot 1$ & $10 \cdot 7$ & $5 \cdot 6-16 \cdot 2$ & $10 \cdot 7$ & $3.7-26.5$ & $13 \cdot 5$ & $4 \cdot 8-40 \cdot 5$ \\
\hline Ionised $\mathrm{Ca}(\mathrm{mmol} / \mathrm{l})$ & $1 \cdot 3$ & $1 \cdot 1-1 \cdot 3$ & $1 \cdot 3$ & $1 \cdot 3-1.4$ & 1.3 & $1 \cdot 3-1 \cdot 4^{*}$ & 1.4 & $1 \cdot 3-1 \cdot 4$ \\
\hline $\mathrm{P}(\mathrm{mmol} / \mathrm{l})$ & 1.3 & $1.1-1.4$ & 1.3 & $1.1-1.5$ & 1.4 & $1 \cdot 2-1 \cdot 7$ & 1.3 & $1 \cdot 1-1 \cdot 6$ \\
\hline Creatinine $(\mu \mathrm{mol} / \mathrm{l})$ & 88.4 & $70.7-114.9$ & $97 \cdot 2$ & $70 \cdot 7-114.9$ & $97 \cdot 2$ & $61 \cdot 9-132 \cdot 6$ & $106 \cdot 1$ & $53.0-114.9$ \\
\hline
\end{tabular}

PTH, parathyroid hormone.

* Values were significantly different between pre-trial control and treatment groups $(P=0.02$; Wilcoxon two-sample test).

$\dagger$ Daily oral vitamin $D_{3}$ supplementation, $2.3 \mu \mathrm{g} / \mathrm{kg}^{0.75}$.

Table 4. Serum concentrations of vitamin D metabolites in control $(n 6)$ and treatment $(n 7)$ groups as measured by HPLC at the conclusion of the vitamin D supplementation trial

(Mean values and standard deviations)

\begin{tabular}{|c|c|c|c|c|}
\hline \multirow[b]{3}{*}{ Vitamin D metabolite } & \multicolumn{4}{|c|}{ Group } \\
\hline & \multicolumn{2}{|c|}{ Control } & \multicolumn{2}{|c|}{ Treatment $^{*}$} \\
\hline & Mean & SD & Mean & SD \\
\hline $25(\mathrm{OH}) \mathrm{D}_{3}(\mathrm{ng} / \mathrm{ml})$ & 40.4 & 9.9 & $47 \cdot 8$ & $6 \cdot 4$ \\
\hline $25(\mathrm{OH}) \mathrm{D}_{2}(\mathrm{ng} / \mathrm{ml})$ & ND & & ND & \\
\hline $24 \mathrm{R}, 25(\mathrm{OH})_{2} \mathrm{D}_{3}(\mathrm{ng} / \mathrm{ml})$ & $17 \cdot 7$ & 6 & 18.5 & 3.7 \\
\hline
\end{tabular}

25(OH) $\mathrm{D}_{3}$, 25-hydroxyvitamin $\mathrm{D}_{3} ; 25(\mathrm{OH}) \mathrm{D}_{2}, 25$-hydroxyvitamin $\mathrm{D}_{2} ; \mathrm{ND}$, not detected (<1.0 ng/ml); 24R,25(OH) $)_{2} \mathrm{D}_{3}, 24 \mathrm{R}, 25$-dihydroxyvitamin $\mathrm{D}_{3}$.

${ }^{*}$ Daily oral vitamin $\mathrm{D}_{3}$ supplementation, $2 \cdot 3 \mu \mathrm{g} / \mathrm{kg}^{0.75}$.

\section{5-Hydroyxvitamin $D_{3}$ storage stability trial}

The $25(\mathrm{OH}) \mathrm{D}_{3}$ concentrations in samples stored at $4^{\circ} \mathrm{C}$ for 2 , $4,7,10$ and $14 \mathrm{~d}$ were not significantly different from that determined on day 0 . Likewise, the $25(\mathrm{OH}) \mathrm{D}_{3}$ concentrations in samples stored at -20 and $-80^{\circ} \mathrm{C}$ for $1,2,3,5,7,9,12$ and 15 weeks were not significantly different from that determined on day 0.

\section{Discussion}

Our objective in evaluating the effectiveness of oral vitamin D supplementation to improve vitamin D status in apparently healthy adult dogs is based upon previous findings that dogs with chronic disease have lower vitamin $\mathrm{D}$ concentrations ${ }^{(10,16-19)}$. Similar to studies in human medicine, investigators of a recent study defined vitamin D sufficiency in a large cohort of adult dogs through the evaluation of biomarkers that are affected by vitamin $\mathrm{D}$ status ${ }^{(10)}$. The serum $25(\mathrm{OH}) \mathrm{D}$ concentration of dogs at an apparent asymptotic minimum of serum PTH concentration was found to be $100 \mathrm{ng} / \mathrm{ml}$. To our knowledge this is the first published report defining sufficient vitamin D status in the adult dog in the maintenance state. While we believe that much investigation is needed to confirm this definition of vitamin $\mathrm{D}$ sufficiency, we also believe that research such as ours that evaluates a means to achieve a serum $25(\mathrm{OH}) \mathrm{D}$ concentration of $100 \mathrm{ng} / \mathrm{ml}$ is warranted.
Our finding that the majority $(71.7 \%)$ of apparently healthy dogs that we evaluated had serum $25(\mathrm{OH}) \mathrm{D}$ concentrations below $100 \mathrm{ng} / \mathrm{ml}$ (Fig. 1) is consistent with findings of recent studies ${ }^{(10,13)}$. The reason for this finding in dogs is unknown, but many factors including vitamin $\mathrm{D}$ inclusion differences in diets and individual variation in intake, absorption and metabolism of vitamin D are probably contributing. Unfortunately, the amount of vitamin $\mathrm{D}$ in the diet necessary to achieve a specific health outcome may be difficult to determine. One reason is that dietary vitamin $\mathrm{D}$ analyses may not account for all vitamin D activity. For example, adipose tissue and liver, which are common ingredients of dog foods, may contain substantial amounts of $25(\mathrm{OH}) \mathrm{D}$ relative to vitamin $\mathrm{D}^{(23)}$. Whereas the assayed vitamin $\mathrm{D}$ content of a dog food may be available upon request from a manufacturer; the $25(\mathrm{OH}) \mathrm{D}$ content of dog foods is not generally reported, and we suspect that it is not typically determined. Whether oral $25(\mathrm{OH}) \mathrm{D}$ has greater potency in raising vitamin $\mathrm{D}$ status in dogs is currently being investigated by the authors. In humans, ingested $25(\mathrm{OH}) \mathrm{D}$ has been shown to be many times more effective than vitamin $\mathrm{D}$ in raising serum $25(\mathrm{OH}) \mathrm{D}^{(24)}$.

Also problematic for determining sufficient dietary vitamin $\mathrm{D}$ inclusion for all dogs are factors evidenced to influence serum $25(\mathrm{OH}) \mathrm{D}$ concentrations in dogs, such as sex (males $>$ females), reproductive status (intact $>$ neutered) and breed ${ }^{(13)}$. The effect of reproductive status could not be confirmed with the current cohort studied, given that all but one $\operatorname{dog}$ was neutered. However, this may be one factor contributing to the low vitamin D status in the large majority of the dogs evaluated in this study.

Although serum 25(OH)D concentration is believed to indicate vitamin $\mathrm{D}$ status in dogs, it should be noted that methods by which $25(\mathrm{OH}) \mathrm{D}$ concentrations are assayed are not standardised, which can complicate the interpretation of results ${ }^{(25-27)}$. In our study, the CLIA method was used to measure total $25(\mathrm{OH}) \mathrm{D}$ concentrations, while a published HPLC method $^{(21)}$ was used to quantify vitamin D metabolites not attainable through an immunoassay. We found that serum 25 $(\mathrm{OH}) \mathrm{D}$ concentrations determined by HPLC compared with those determined by the CLIA method used by the commercial laboratory were positively correlated but consistently lower (data not shown). This methodological difference was similar to that 
reported by Lensmeyer $e t$ al. ${ }^{(21)}$, the investigators from whom we adapted our HPLC methodology. Chromatographic methods, such as HPLC and LC/MS, compared with immunologically based methods like CLIA are touted as more accurate ${ }^{(26)}$.

The most significant finding in our study was only a modest difference $(12 \%)$ in vitamin D status when dogs are given an oral dosage of vitamin $\mathrm{D}$ that we believed to be substantial (Fig. 2). While a significant difference was found in serum $25(\mathrm{OH}) \mathrm{D}$ concentrations between the control and treatment groups at weeks $9-10$, serum $25(\mathrm{OH}) \mathrm{D}$ concentrations of no dog in the treatment group increased to the reported sufficient vitamin D concentrations of $100 \mathrm{ng} / \mathrm{ml}$. Therefore, our findings question the relevance of our vitamin $\mathrm{D}_{3}$ supplementation to achieve a specific health outcome in adult dogs. The reason our vitamin $\mathrm{D}$ supplementation was ineffective was not apparent; however, several possibilities to explain the results were investigated and are further discussed here.

To control for variables that have been reported to affect changes in serum $25(\mathrm{OH}) \mathrm{D}$ concentrations in people ${ }^{(28,29)}$, such as age, sex and BW, the control and treatment groups were balanced. These were not obese dogs on average, and the groups were of similar body conditions, so excess body fat, and therefore storage of vitamin $\mathrm{D}_{3}$ in adipose tissue, would not probably explain the weak response to vitamin D supplementation in our subjects.

The treatment schedule used in this supplementation trial followed that of a published human dose-response study that showed near-asymptotic serum $25(\mathrm{OH}) \mathrm{D}$ concentrations after approximately 10 weeks of daily oral administration of vitamin $\mathrm{D}_{3}$, irrespective of dose ${ }^{(30)}$. In this work on healthy human subjects, the greatest rise in serum $25(\mathrm{OH}) \mathrm{D}$ concentrations from baseline occurred within the first 3 weeks of supplementation. While it is unknown whether dogs respond to supplementation as humans do, it was anticipated that our study design would allow us to capture the early rise in 25 $(\mathrm{OH}) \mathrm{D}$ in response to supplementation. After finding a weak response in $25(\mathrm{OH}) \mathrm{D}$ concentrations of our treatment group, the trial was ended at 10 weeks, given we were unlikely to have further significant results maintaining this dose between the two groups in this trial.

In order to evaluate a practical means to vitamin D supplementation in dogs, an oral and voluntary route of administration was chosen in favour of intramuscular or intravenous routes. As a fat-soluble vitamin, D requires the presence of fat in the diet for adequate absorption in the animal. It is reasonable to believe the provision of vitamin $\mathrm{D}$ in an oil vehicle, as is typically used in human vitamin D supplements, and given with a meal would be absorbed in the healthy dog. As vitamin $\mathrm{D}$ dosing studies have not been reported in adult dogs, specifically for the intention of improving vitamin D status, the dosage of vitamin $\mathrm{D}$ supplementation chosen was kept just below the NRC recommended safe upper limit. To our knowledge, a minimum toxic oral dose of vitamin $\mathrm{D}$ has not been reported for adult dogs, so the NRC recommendation was heeded. Dietary vitamin D toxicity resulted in clinical signs and biochemical disturbances in two adult dogs when accidental over-supplementation was approximately twenty-nine times the safe upper limit ${ }^{(12)}$. A study in puppies fed a dietary concentration of approximately seventeen times the safe upper limit also did not result in clinical signs of vitamin D toxicity, but severely disturbed endochondral ossification ${ }^{(31)}$. Therefore, the dose of vitamin $\mathrm{D}_{3}$ supplement given, while not inconsequential, was not expected to result in toxicity.

Lacking receipt of vitamin D supplement by dogs and a decline in strength of supplement were not believed to be contributing factors in our results. Owner compliance was assessed by weighing the supplement prior to dispensing and at the end of the trial, as an indication that the supplement was being given in adequate amounts. Owners did not report problems with lack of intake by the dogs when the supplement in oil was applied on food. In addition, the retention of vitamin $D_{3}$ in the supplements dispensed to owners as measured at the conclusion of the trial was still near the safe upper limit for vitamin $\mathrm{D}$ according to the NRC.

Serum concentrations of $24 \mathrm{R}, 25(\mathrm{OH})_{2} \mathrm{D}_{3}$ in dogs have been reported to be higher than found in humans ${ }^{(32)}$ and other domestic species ${ }^{(33)}$. Investigation into the possible metabolic conversion of $25(\mathrm{OH}) \mathrm{D}$ by the dogs to $24 \mathrm{R}, 25(\mathrm{OH})_{2} \mathrm{D}_{3}$ was conducted at the conclusion of the supplementation trial. As a major metabolite of $25(\mathrm{OH}) \mathrm{D}, 24 \mathrm{R}, 25(\mathrm{OH})_{2} \mathrm{D}_{3}$ is produced in dogs by 24-hydroxlyase in the kidney and intestine ${ }^{(34)}$. Concentration of $24 \mathrm{R}, 25(\mathrm{OH})_{2} \mathrm{D}_{3}$ in serum is well-established to positively correlate with serum $25(\mathrm{OH}) \mathrm{D}$ concentration $^{(31,35)}$. This correlation has been documented in a study of puppies that reported that serum $24 \mathrm{R}, 25(\mathrm{OH})_{2} \mathrm{D}_{3}$ concentrations were significantly higher in a treatment group consuming eight times the dietary vitamin $\mathrm{D}$ as the control group ${ }^{(35)}$. This difference in $24 \mathrm{R}, 25(\mathrm{OH})_{2} \mathrm{D}_{3}$ concentrations was found after 6 weeks of supplementation, whereas $25(\mathrm{OH}) \mathrm{D}$ concentrations did not differ between the groups during the trial. In the present study, serum concentrations of $24 \mathrm{R}, 25(\mathrm{OH})_{2} \mathrm{D}_{3}$ of the treatment group dogs were not significantly different from those of the control group dogs (Table 4). Therefore, it is reasonable to conclude that an increased metabolic loss of $25(\mathrm{OH}) \mathrm{D}$ to $24 \mathrm{R}, 25(\mathrm{OH})_{2} \mathrm{D}_{3}$ does not explain the weak response that occurred in our treatment group to vitamin $\mathrm{D}$ supplementation.

A plausible explanation for the weak serum $25(\mathrm{OH}) \mathrm{D}$ response to our vitamin $\mathrm{D}$ supplementation might be low bioavailability of the supplement. Studies on factors affecting vitamin $\mathrm{D}$ absorption by dogs, distribution and metabolism of absorbed vitamin D are needed. Reports of supplement vehicle effects on oral vitamin $\mathrm{D}$ bioavailability are sparse ${ }^{(36)}$. To our knowledge vitamin $\mathrm{D}$ bioavailability comparisons between supplementation and dietary inclusion are lacking for dogs. Vitamin D infused into the portal blood of dogs is efficiently removed by the liver ${ }^{(37)}$. Therefore, a poor response in serum 25(OH)D to oral vitamin D supplementation in dogs could reflect extrahepatic uptake of vitamin $\mathrm{D}$, such as into adipose tissue, and/or altered 25-hydroxlyation of vitamin $\mathrm{D}$ by the liver. Also, within the liver of dogs, $25(\mathrm{OH}) \mathrm{D}$ concentrations are reported to be as great as those of vitamin $\mathrm{D}^{(38)}$, and rate of 25-hydroxylation of vitamin $\mathrm{D}$ can be experimentally varied ${ }^{(39)}$.

A limitation of the present study is the small sample size. While our study design was of sufficient power to show that 
by the trial end (weeks 9-10) dogs receiving the vitamin $\mathrm{D}_{3}$ supplement had higher $25(\mathrm{OH}) \mathrm{D}$ concentrations as compared with control dogs, no dog in the treatment group reached the reported $25(\mathrm{OH}) \mathrm{D}$ concentration indicative of sufficiency. In addition, the inverse relationship between PTH and serum $25(\mathrm{OH}) \mathrm{D}$ concentrations that has previously been found in dogs was not evident in the present study. This was probably a result of large between-individual variance in PTH with any given serum $25(\mathrm{OH}) \mathrm{D}$ concentration in combination with our small group sizes not revealing the correlation.

In conclusion, our findings support those of others in that apparently healthy adult dogs vary significantly in their serum concentration of $25(\mathrm{OH}) \mathrm{D}$, the indicator of vitamin $\mathrm{D}$ status. We performed a prospective trial in dogs with 25 $(\mathrm{OH}) \mathrm{D}$ concentrations below $100 \mathrm{ng} / \mathrm{ml}$ to assess the effectiveness of an oral dosage of vitamin $\mathrm{D}$ to improve their vitamin D status. We found a lesser response than anticipated at a daily dose of approximately $2.3 \mu \mathrm{g} / \mathrm{kg} \mathrm{BW}^{0.75}$, which is substantially more vitamin $\mathrm{D}_{3}$ than the amount provided by these dogs' commercially available diets. In light of the fact that this is the first study of its kind to report these findings in dogs, further investigation must be done before dosing recommendations can be made for dogs with low vitamin D status.

\section{Supplementary material}

The supplementary material for this article can be found at http://dx.doi.org/10.1017/jns.2016.23

\section{Acknowledgements}

The authors thank Lada Micheas for her assistance with statistical analyses and owners of dogs for their participation.

This work was supported by the Nestle Purina Endowed Program in Small Animal Nutrition, College of Veterinary Medicine, University of Missouri, Columbia, MO 65211, USA. The funders had no role in the design, analysis or writing of this article.

L.R. Y. was the co-investigator of the study, contributing to the study design, analyses of data, and writing the manuscript. R. C. B. was the principal investigator of the study, contributing to the study design, processing and analysing data, and writing the manuscript.

There are no conflicts of interest.

\section{References}

1. Norman AW (2012) The history of the discovery of vitamin D and its daughter steroid hormone. Ann Nutr Metab 61, 199-206.

2. Stöcklin EEM (2013) Vitamin D, an essential nutrient with versatile functions in nearly all organs. Int J Vitam Nutr Res 83, 92-100.

3. Chapuy MC, Preziosi P, Maamer M, et al. (1997) Prevalence of vitamin D insufficiency in an adult normal population. Osteoporos Int 7, 439-443.

4. Dawson-Hughes B, Heaney RP, Holick MF, et al. (2005) Estimates of optimal vitamin D status. Osteoporos Int 16, 713-716.

5. Saliba W, Barnett O, Rennert HS, et al. (2011) The relationship between serum $25(\mathrm{OH}) \mathrm{D}$ and parathyroid hormone levels. Am J Med 124, 1165-1170.
6. Vieth R, Ladak Y \& Walfish PG (2003) Age-related changes in the 25-hydroxyvitamin $\mathrm{D}$ versus parathyroid hormone relationship suggest a different reason why older adults require more vitamin $\mathrm{D}$. J Clin Endocrinol Metab 88, 185-191.

7. Steingrimsdottir L, Gunnarsson O, Indridason OS, et al. (2005) Relationship between serum parathyroid hormone levels, vitamin $\mathrm{D}$ sufficiency, and calcium intake. JAMA 294, 2336-2341.

8. Holick MF, Binkley NC, Bischoff-Ferrari HA, et al. (2011) Evaluation, treatment, and prevention of vitamin D deficiency: an Endocrine Society clinical practice guideline. J Clin Endocrinol Metab 96, 1911-1930.

9. Bischoff-Ferrari HA, Shao A, Dawson-Hughes B, et al. (2010) Benefit-risk assessment of vitamin D supplementation. Osteoporos Int 21, 1121-1132.

10. Selting KA, Sharp CR, Ringold R, et al. (2014) Serum 25-hydroxyvitamin D concentrations in dogs - correlation with health and cancer risk. Vet Comp Oncol (epublication ahead of print version 8 July 2014).

11. Fairweather AAC, Eason CT, Elder PA, et al. (2013) Reference concentrations of cholecalciferol in animals: a basis for establishing non-target exposure. New Zeal J Zool 40, 280-289.

12. Mellanby RJ, Mee AP, Berry JL, et al. (2005) Hypercalcaemia in two dogs caused by excessive dietary supplementation of vitamin D. J Small Anim Pract 46, 334-338.

13. Sharp CR, Selting KA \& Ringold R (2015) The effect of diet on serum 25-hydroxyvitamin $\mathrm{D}$ concentrations in dogs. BMC Res Notes 8, 442.

14. How KL, Hazewinkel HA \& Mol JA (1994) Dietary vitamin D dependence of cat and dog due to inadequate cutaneous synthesis of vitamin D. Gen Comp Endocrinol 96, 12-18.

15. National Research Council Ad Hoc Committee on Dog and Cat Nutrition (2006) Vitamins. In Nutrient Requirements of Dogs and Cats, pp. 193-245. Washington, DC: The National Academies Press.

16. Wakshlag JJ, Rassnick KM, Malone EK, et al. (2011) Cross-sectional study to investigate the association between vitamin $\mathrm{D}$ status and cutaneous mast cell tumours in Labrador retrievers. $\mathrm{Br}$ J Nutr 106, S60-S63.

17. Gerber B, Hassig M \& Reusch CE (2003) Serum concentrations of 1,25-dihydroxycholecalciferol and 25-hydroxycholecalciferol in clinically normal dogs and dogs with acute and chronic renal failure. Am J Vet Res 64, 1161-1166.

18. Kraus MS, Rassnick KM, Wakshlag JJ, et al. (2014) Relation of vitamin D status to congestive heart failure and cardiovascular events in dogs. J Vet Intern Med 28, 109-115.

19. Gow AG, Else R, Evans H, et al. (2011) Hypovitaminosis D in dogs with inflammatory bowel disease and hypoalbuminaemia. J Small Anim Pract 52, 411-418.

20. National Research Council Ad Hoc Committee on Dog and Cat Nutrition (2006) Nutrient requirements and dietary nutrient concentrations. In Nutrient Requirements of Dogs and Cats, pp. 354-370. Washington, DC: The National Academies Press.

21. Lensmeyer GL, Wiebe DA, Binkley N, et al. (2006) HPLC method for 25-hydroxyvitamin D measurement: comparison with contemporary assays. Clin Chem 52, 1120-1126.

22. Garg S, Sabri D, Kanji J, et al. (2013) Evaluation of vitamin D medicines and dietary supplements and the physicochemical analysis of selected formulations. J Nutr Health Aging 17, 158-161.

23. Jakobsen J, Clausen I, Leth T, et al. (2004) A new method for the determination of vitamin $\mathrm{D}_{3}$ and 25-hydroxyvitamin $\mathrm{D}_{3}$ in meat. J Food Compost Anal 17, 777-787.

24. Stamp TC, Haddad JG \& Twigg CA (1977) Comparison of oral 25-hydroxycholecalciferol, vitamin $\mathrm{D}$, and ultraviolet light as determinants of circulating 25-hydroxyvitamin D. Lancet 309, 1341-1343.

25. Binkley N, Krueger D, Cowgill CS, et al. (2004) Assay variation confounds the diagnosis of hypovitaminosis D: a call for standardization. J Clin Endocrinol Metab 89, 3152-3157.

26. Binkley N \& Wiebe D (2013) Clinical controversies in vitamin D: $25(\mathrm{OH}) \mathrm{D}$ measurement, target concentration, and supplementation. J Clin Densitom 16, 402-408. 
27. Lips P, Chapuy MC, Dawson-Hughes B, et al. (1999) An international comparison of serum 25-hydroxyvitamin D measurements. Osteoporos Int 9, 394-397.

28. Didriksen A, Grimnes G, Hutchinson MS, et al. (2013) The serum 25-hydroxyvitamin D response to vitamin D supplementation is related to genetic factors, BMI, and baseline levels. Eur J Endocrinol 169, 559-567.

29. Shab-Bidar S, Bours SP, Geusens PP, et al. (2013) Suboptimal effect of different vitamin $\mathrm{D}_{3}$ supplementations and doses adapted to baseline serum $25(\mathrm{OH}) \mathrm{D}$ on achieved $25(\mathrm{OH}) \mathrm{D}$ levels in patients with a recent fracture: a prospective observational study. Eur J Endocrinol 169, 597-604.

30. Heaney RP, Davies KM, Chen TC, et al. (2003) Human serum 25-hydroxycholecalciferol response to extended oral dosing with cholecalciferol. Am J Clin Nutr 77, 204-210.

31. Tryfonidou MA, Holl MS, Stevenhagen JJ, et al. (2003) Dietary 135-fold cholecalciferol supplementation severely disturbs the endochondral ossification in growing dogs. Domest Anim Endocrinol 24, 265-285.

32. Berg AH, Powe CE, Evans MK, et al. (2015) 24,25-Dihydroxyvitamin $\mathrm{D}_{3}$ and vitamin $\mathrm{D}$ status of community-dwelling black and white Americans. Clin Chem 61, $877-884$.
33. Horst RL \& Littledike ET (1982) Comparison of plasma concentrations of vitamin $\mathrm{D}$ and its metabolites in young and aged domestic animals. Com Biochem Physiol B 73, 485-489.

34. Tryfonidou MA, Oosterlaken-Dijksterhuis MA, Mol JA, et al. (2003) 24-Hydroxylase: potential key regulator in hypervitaminosis $\mathrm{D}_{3}$ in growing dogs. Am J Physiol Endocrinol Metab 284, E505-E513.

35. Tryfonidou MA, Stevenhagen JJ, van den Bemd GJ, et al. (2002) Moderate cholecalciferol supplementation depresses intestinal calcium absorption in growing dogs. J Nutr 132, 2644-2650.

36. Grossmann RE \& Tangpricha V (2010) Evaluation of vehicle substances on vitamin D bioavailability: a systematic review. Mol Nutr Food Res 54, 1055-1061.

37. Gascon-Barre M \& Huet PM (1982) Role of the liver in the homeostasis of calciferol metabolism in the dog. Endocrinology 110, 563570 .

38. Sonne C, Kirkegaard M, Jakobsen J, et al. (2014) Altered vitamin D status in liver tissue and blood plasma from Greenland sledge dogs (Canis familiaris) dietary exposed to organohalogen contaminated minke whale (Balaenoptera acuterostrata) blubber. Ecotoxicol Environ Saf 104, 403-408.

39. Gascon-Barre M, Vallieres S \& Huet PM (1986) Influence of phenobarbital on the hepatic handling of $\left[{ }^{3} \mathrm{H}\right]$ vitamin $\mathrm{D}_{3}$ in the dog. Am J Physiol 251, G627-G635. 